\title{
ARTIGOS
}

\section{Development of a molecular method for detection and identification of Xanthomonas campestris pv. viticola}

\author{
Loiselene Carvalho da Trindade ${ }^{1}$, Eder Marques ${ }^{1}$, Daniela Biaggioni Lopes ${ }^{2}$, Marisa Álvares da Silva Velloso Ferreira ${ }^{1}$
}

${ }^{1}$ Departamento de Fitopatologia, Universidade de Brasília, CEP 70910-900, Brasília, DF, e-mail: marisavf@unb.br; ${ }^{2}$ EMBRAPA-Semi Árido, C.P. 23, CEP 56300-970, Petrolina, PE.

Autora para correspondência: Marisa A. S. Velloso Ferreira

Data de chegada: 14/03/2005. Aceito para publicação em: 04/05/2006.

\begin{abstract}
Trindade, L.C.; Marques, E.; Lopes, D.B.; Ferreira, M.A.S.V. Development of a molecular method for detection and identification of Xanthomonas campestris pv. viticola. Summa Phytopathologica, v.33, n.1, p.16-23, 2007.

In order to develop a molecular method for detection and identification of Xanthomonas campestris pv. viticola $(X c v)$ the causal agent of grapevine bacterial canker, primers were designed based on the partial sequence of the $h r p B$ gene. Primer pairs Xcv1F/Xcv3R and RST2/ Xcv3R, which amplified 243- and 340-bp fragments, respectively, were tested for specificity and sensitivity in detecting DNA from $X c v$. Amplification was positive with DNA from $44 \mathrm{Xcv}$ strains and with DNA from four strains of $X$. campestris pv. mangiferaeindicae and five strains of $X$. axonopodis pv. passiflorae, with both primer pairs. However, the enzymatic digestion of PCR products could differentiate $X c v$ strains from the others. None of the primer pairs amplified DNA from grapevine, from 20 strains of nonpathogenic bacteria from grape leaves and 10

strains from six representative genera of plant pathogenic bacteria. Sensitivity of primers Xcv1F/Xcv3R and RST2/Xcv3R was $10 \mathrm{pg}$ and 1 pg of purified $X c v$ DNA, respectively. Detection limit of primers RST2/ Xcv3R was $10^{4} \mathrm{CFU} / \mathrm{ml}$, but this limit could be lowered to $10^{2} \mathrm{CFU} / \mathrm{ml}$ with a second round of amplification using the internal primer Xcv1F. Presence of $X c v$ in tissues of grapevine petioles previously inoculated with $X c v$ could not be detected by PCR using macerated extract added directly in the reaction. However, amplification was positive with the introduction of an agar plating step prior to PCR. Xcv could be detected in $1 \mu \mathrm{l}$ of the plate wash and from a cell suspension obtained from a single colony. Bacterium identity was confirmed by RFLP analysis of the RST2/Xcv3R amplification products digested with Hae III.
\end{abstract}

Additional key words: PCR, grapevines, Vitis vinifera, bacterial canker

\section{RESUMO}

Trindade, L.C.; Marques, E.; Lopes, D.B.; Ferreira, M.A.S.V. Desenvolvimento de um método molecular para detecção e identificação de Xanthomonas campestris pv. viticola. Summa Phytopathologica, v.33, n.1, p.16-23, 2007.

Com o objetivo de desenvolver um método molecular para detecção e identificação de Xanthomonas campestris pv. viticola (Xcv), agente causal do cancro bacteriano da videira, oligonucleotídeos (primers) foram desenhados com base na sequiência parcial do gene $h r p B$. As combinações de primers $\mathrm{Xcv} 1 \mathrm{~F} / \mathrm{Xcv} 3 \mathrm{R}$ e RST2/Xcv3R que amplificaram fragmentos de 243 e $340 \mathrm{pb}$, respectivamente, foram testadas quanto à especificidade e sensibilidade para detecção do DNA de Xcv. Com os dois pares de primers, amplificação foi positiva com o DNA de 44 isolados de $X c v$, mas também com quatro isolados de X.c. pv. mangiferaeindicae e cinco de $X$. axonopodis pv. passiflorae. Contudo, a digestão dos produtos de PCR permitiu diferenciar Xcv dos isolados desses patovares. Nenhum dos dois pares de primers amplificou o DNA de videira, nem de 20 bactérias não patogênicas isoladas da flora da videira, ou de 10 isolados de outros seis gêneros de bactérias

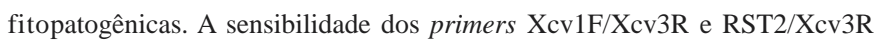
foi de $10 \mathrm{pg}$ e $1 \mathrm{pg}$ de DNA purificado de $X c v$, respectivamente. O limite de detecção de RST2/Xcv3R foi de $10^{4} \mathrm{UFC} / \mathrm{ml}$, mas empregando-se uma segunda rodada de amplificação com o primer interno Xcv1F, esse limite foi de $10^{2} \mathrm{UFC} / \mathrm{ml}$. Não foi possível detectar por PCR a presença de $X c v$ usando-se, diretamente na reação, o extrato do macerado de pecíolos de videira previamente inoculados. Entretanto, amplificações foram positivas quando se utilizou uma etapa de enriquecimento em meio de cultura antes da PCR. Detectou-se Xcv em $1 \mu$ da suspensão obtida do lavado das placas e em uma suspensão obtida a partir de uma única colônia. A identidade da bactéria foi confirmada pela análise de RFLP dos produtos de amplificação dos primers $\mathrm{RST} 2 / \mathrm{Xcv} 3 \mathrm{R}$ com HaeIII. 
Xanthomonas campestris pv. viticola (Nayudu) Dye (21) is the causal agent of grapevine canker disease, an important bacterial disease of grapevines in northeastern Brazil. This pathogen was first reported in the irrigated areas of the São Francisco river basin in Petrolina, state of Pernambuco (18). Later, the disease was also detected in Juazeiro, state of Bahia, and in the states of Piauí (17) and Ceará (8). Xanthomonas campestris pv.viticola is a gramnegative, non-pigmented bacterium which presents the following characteristics: aerobic metabolism, does not produce urease and oxidase but produces catalase, does not utilize asparagine as the sole source of $\mathrm{C}$ and $\mathrm{N}$, tolerates up to $2 \% \mathrm{NaCl}$, and produces acid from glucose, mannose, galactose, trehalose, cellobiose and fructose $(6,14,18,21)$. The disease is characterized by necrotic leaf spots, which sometimes coalesce, producing extensive necrosis. Symptoms also develop on leaf veins, petioles, pedicels and rachis of grape clusters. Cankers and vascular discoloration are usually observed on stems $(14,18,21)$. Integrated management of bacterial canker can be achieved by the use of healthy propagative material, routine field inspections, drastic pruning of infected plants, roguing, management of production periods, disinfestation of vehicles, equipments and pruning tools, the use of copper and thiocarbamats as protecting fungicides, the use of windbreaks and localized irrigation to reduce bacterial dissemination $(14,20)$.

Diagnosis of grapevine bacterial canker is based on symptoms developed on leaves, grape clusters and stems, followed by bacterial isolation and identification using biochemical and nutritional tests. Identification at the pathovar level depends on pathogenicity tests on grapevine susceptible varieties, with a period of 7-12 days for development of the first symptoms $(14,18)$. Detecting and identifying X. c. pv. viticola in grapevine plant parts and/or propagative material, either symptomatic or asymptomatic, can be a time-consuming task with the currently available methods. Serological and molecular methods are more sensitive and specific and can improve the diagnosis of bacterial diseases. Polyclonal antibodies have already been developed for $X$. c. pv. viticola (3), and despite showing weak cross-reaction with $X . c$. pv. campestris, X. c. pv. vesicatoria and X. c. pv. mangiferaeindicae, they can potentially be used in serological tests for specific identification of $X . c$. pv.viticola.

Polymerase chain reaction (PCR) has been widely used and shown to have multiple applications in plant disease diagnosis, including several bacterial diseases $(9,11,16,22,23)$. PCR-based detection methods offers several advantages such as high sensitivity to detect small amounts of DNA in infected or asymptomatic materials, without requiring organism culturing (19).

In plant pathogenic bacteria, several genomic regions have been explored in order to design primers for PCR-based detection, such as the ribosomal DNA spacer regions and the hrp gene cluster (16). The hrp genes have been discovered and characterized in several bacterial plant pathogens and they play a role in both hypersensitivity reaction and pathogenicity (15). Hrp genes are highly conserved in the genus Xanthomonas and they can be used to differentiate Xanthomonas strains both at pathovar and species levels. Leite Jr. et al. $(12,13)$ designed specific primers based on the corresponding region of the $h r p B$ gene for the detection and identification of $X$. campestris pv. vesicatoria by PCR. Roberts et al. (23) also demonstrated that the amplification and sequencing of a $h r p$-gene region allowed the selection of highly specific primers with high sensitivity for detecting $X$. fragariae in both symptomatic and asymptomatic strawberry plants. Specific primers based on hrp sequences are particularly useful for detection of pathogenic xanthomonads, since nonpathogenic strains lack these genes (12).

Xanthomonas campestris pv. viticola is considered a pathogen of quarantine importance. The use of pathogen-free propagative material has become an important concern, considering the very restricted occurrence of this pathogen in the country and the risk of its establishment in other grapevine producing regions in south and southeast Brazil. Thus, the development of rapid and reliable procedures for detecting and identifying this pathogen is an important step for disease management in the affected areas, as well as for preventing its spread to other regions in the country. The objective of this work was to develop primers and to evaluate their potential for detection and identification of X.c. pv. viticola by PCR.

\section{MATERIALS AND METHODS}

\section{Bacterial strains: origin and maintenance}

Forty-one Xanthomonas campestris pv. viticola strains collected in grapevine producing areas in the "Submédio" of the São Francisco river valley, states of Pernambuco and Bahia, were used in this study. The strains were collected from 1998- 2003, from various grapevine cultivars. Two strains collected in Teresina, Piauí, and the reference strain of this bacterium (NCPPB 2475) were also included. Forty-two strains of Xanthomonas isolated from various host plants, as well as 10 strains belonging to six other genera of phytopathogenic bacteria, and 20 strains of epiphytic and/or endophytic bacteria isolated from grape leaves, were included to determine primer specificity (Table 1 ). All strains were cultivated on Kado's 523 medium (10). For long-term storage, strains were kept on sterile distilled water at room temperature and frozen in $30 \%$ glycerol at $-80{ }^{\circ} \mathrm{C}$.

\section{DNA Extraction}

DNA was extracted from grape leaves according to the protocol described by Doyle \& Doyle (7). Bacterial DNA was extracted using a modified version of the CTAB method from Ausubel et al. (4). Single colonies grown on Kado's 523 medium were transferred to $1.5 \mathrm{ml}$ of liquid 523 medium and cultures were grown on a shaker for $48 \mathrm{~h}$ at $28{ }^{\circ} \mathrm{C}$. After this period, cultures were centrifuged at 4600x $\mathrm{g}$ for $5 \mathrm{~min}$. The resulting pellets were resuspended in $520 \mu \mathrm{l}$ of TE buffer $(10 \mathrm{mM}$ Tris-HCl, $1 \mathrm{mM}$ EDTA, pH 8.0). Fifteen microliters of $20 \%$ SDS and $3 \mu 1$ of Proteinase K $(20 \mathrm{mg} / \mathrm{ml})$ were added. The mixture was incubated for 1 hour at $37^{\circ} \mathrm{C}$, then $100 \mu \mathrm{l}$ of $5 \mathrm{M} \mathrm{NaCl}$ and $80 \mu \mathrm{l}$ of a $10 \%$ CTAB solution in $0.7 \mathrm{M} \mathrm{NaCl}$ were added and mixed. The suspension was incubated for $10 \mathrm{~min}$ at $65^{\circ} \mathrm{C}$ and kept on ice for $15 \mathrm{~min}$. An equal volume of chloroform: isoamyl alcohol (24:1) was added, followed by incubation on ice for $5 \mathrm{~min}$ and centrifugation at $7200 \mathrm{x} g$ for $20 \mathrm{~min}$. The aqueous phase was transferred to a new tube, isopropanol (1:0.6) was added and DNA was precipitated at $-20{ }^{\circ} \mathrm{C}$ for $16 \mathrm{~h}$. DNA was collected by centrifugation at $7200 \mathrm{x} g$ for $10 \mathrm{~min}$, washed with $500 \mu \mathrm{l}$ of $70 \%$ ethanol, air-dried at room temperature for approximately three hours and finally dissolved in $50 \mu$ of TE buffer. DNA was quantified on $0.8 \%$ agarose gels by comparison with DNA samples (phage $\lambda$ DNA-Hind III fragments) of known concentration, diluted to working aliquots of $50 \mathrm{ng} / \mu \mathrm{l}$ and stored at $-20^{\circ} \mathrm{C}$.

Amplification and sequencing of a $h r p B$ region of $X . c$. pv. viticola Primers RST2 and RST3 (12) were used to amplify a 840-bp 
Table 1. Bacterial strains used in this study.

\begin{tabular}{|c|c|c|}
\hline Organism & $\begin{array}{c}\text { Number of } \\
\text { isolates }\end{array}$ & Host \\
\hline Agrobacterium tumefaciens & 01 & Daucus carota \\
\hline Bacillus thurigiensis & 01 & - \\
\hline Clavibacter michiganensis subsp. michiganensis & 02 & Lycopersicon esculentum \\
\hline Pseudomonas cichorii & 01 & Lactuca sativa \\
\hline Pseudomonas corrugata & 01 & Lycopersicon esculentum \\
\hline Ralstonia solanacearum & 02 & Dianthus caryophillus \\
\hline Ralstonia solanacearum & 01 & Solanum tuberosum \\
\hline X. axonopodis pv. glycines & 04 & Glycine $\max$ \\
\hline X. axonopodis pv. phaseoli & 03 & Phaseolus vulgaris \\
\hline$X$. axonopodis pv. ricini & 02 & Ricinus communis \\
\hline$X$. campestris pv. arracaciae & 01 & Arracacia xanthorrhiza \\
\hline X. campestris pv. campestris & 05 & Brassica oleraceae \\
\hline X. campestris pv. carotae & 01 & Daucus carota \\
\hline X. campestris pv. mangiferaeindicae & 01 & Anacardium occidentale \\
\hline X. campestris pv. mangiferaeindicae & 03 & Mangifera indica \\
\hline$X$. campestris pv. vesicatoria & 03 & Lycopersicon esculentum \\
\hline X. campestris pv. vesicatoria & 03 & Capsicum spp. \\
\hline$X$. campestris pv. vitians & 01 & Lactuca sativa \\
\hline
\end{tabular}

fragment of the $h r p B$ gene from genomic DNA of X.c. pv. viticola (NCPPB 2475), X.c pv. mangiferaeindicae (UnB 764) and $X$. axonopodis pv. manihotis (UnB 1111). Each PCR mixture contained: $0.5 \mu \mathrm{M}$ of each primer; $200 \mu \mathrm{M}$ dNTPs; $1.5 \mathrm{mM} \mathrm{MgCl2}$; $1 \mathrm{X}$ PCR buffer (20 mM TrisHCl pH 8.4; $50 \mathrm{mM} \mathrm{KCl}$ ); 1.25 U Taq DNA polymerase (Invitrogen, Life Technologies) and $50 \mathrm{ng}$ template DNA in a final volume of $25 \mu \mathrm{l}$. PCR was conducted in a PT-100 thermocycler (MJ Research, Watertown, Mass) using an initial denaturation at $95^{\circ}$ $\mathrm{C}$ for $2 \mathrm{~min}$, followed by 30 cycles of $95^{\circ} \mathrm{C}$ for $1 \mathrm{~min}, 62^{\circ} \mathrm{C}$ for $1 \mathrm{~min}$, $72^{\circ} \mathrm{C}$ for $1 \mathrm{~min}$, and an additional extension step at $72^{\circ} \mathrm{C}$ for $5 \mathrm{~min}$. Specific PCR products from the three representative strains were quantified and adjusted to a final concentration of $70 \mathrm{ng} / \mu \mathrm{l}$. After ethanol precipitation, purified PCR products were sequenced using the dideoxy chain-termination procedure (26) with fluorescent dyes (Dynamic ET terminator Cycle Sequencing Kit, Amersham Biosciences). In each sequencing reaction generating a single-strand template, total volume reaction of $10 \mu \mathrm{l}$ comprised $4 \mu \mathrm{l}$ of sequencing reagent premix, $2 \mu \mathrm{l}$ primer $(10 \mu \mathrm{M}), 1 \mu \mathrm{l}$ PCR product (100 ng) and $3 \mu \mathrm{l}$ sterile water. Sequence reactions were carried out on a Gene Amp PCR System 9700 thermocycler (Applied Biosystems, USA) using 30 cycles of $95^{\circ} \mathrm{C}$ for $20 \mathrm{~s}, 50^{\circ} \mathrm{C}$ for $15 \mathrm{~s}$, and $60^{\circ} \mathrm{C}$ for $1 \mathrm{~min}$. Each product was purified via a standard ethanol precipitation protocol and dissolved in $10 \mu \mathrm{l}$ of Dyenamic ET loading solution (Pharmacia Biotech, USA) for $60 \mathrm{~min}$. Automated sequencing was conducted using a MegaBace 1.000 - DNAAnalyzer System (Pharmacia Biotech,
USA) with an injection voltage of $3 \mathrm{KV}$, an injection time of $60 \mathrm{~s}$, and a running voltage of $9 \mathrm{~V}$. Sequences were verified via BLASTN (1), and alignment conducted using the program Clustal W (29).

\section{Primer design and selection}

Potential primers were identified using program PRIMER 3 (Whitehead Institute for Biomedical Research, Cambridge, Mass.) (24). Three primers were designed and tested in five possible combinations with external primers RST2 and RST3. Primers were synthesized commercially by Invitrogen Brasil (Life Technologies, São Paulo, Brazil). The following criteria were used to choose the best primer pair combination: absence of secondary bands, reproducibility, and positive amplification with all X.c. pv. viticola strains tested.

\section{Primer specificity}

Two out of five possible primer pair combinations (Xcv1F/Xcv3R and RST2/Xcv3) were screened for specificity to X.c. pv. viticola in $12 \mu \mathrm{l}$ - reaction mixtures containing $10 \mathrm{ng}$ of template DNA, $100 \mu \mathrm{M}$ each dNTPs, $1.5 \mathrm{mM} \mathrm{Mg} \mathrm{Cl}, 0.5 \mu \mathrm{M}$ of each primer, $1 \mathrm{X}$ PCR buffer (20 mM TrisHCl pH 8.4; $50 \mathrm{mM} \mathrm{KCl)}$ and $1 \mathrm{U}$ Taq DNA polymerase. All tests were performed in a PT 100 thermocycler (MJ Research, Watertown, Mass) with an initial denaturation step at $95^{\circ} \mathrm{C}$ for $2 \mathrm{~min}$; 30 cycles of $95^{\circ} \mathrm{C}$ for $1 \mathrm{~min}, 64^{\circ} \mathrm{C}$ for $1 \mathrm{~min}$ and $72^{\circ} \mathrm{C}$ for $2 \mathrm{~min}$, and a final extension step of $10 \mathrm{~min}$ at $72^{\circ} \mathrm{C}$. PCR products were analyzed by loading the total reaction volume on $1 \%$ agarose gels and staining 
with ethidium bromide $(0.5 \mu \mathrm{g} / \mathrm{ml})$.

\section{PCR-RFLP}

PCR products from Xanthomonas were digested with endonuclease Hae III (Pharmacia Biotech). Digestions were performed as follows: 6 $\mu 1 \mathrm{PCR}$ product; $1 \mu 110 \mathrm{X}$ enzyme buffer and $2 \mathrm{U}$ of enzyme in a final volume of $10 \mu \mathrm{l}$, at $37^{\circ} \mathrm{C}$ for $16 \mathrm{~h}$. Restriction fragments were separated by electrophoresis in $2.5 \%$ agarose gels or in $21 \%$ polyacrylamide gels and visualized after staining with ethidium bromide.

\section{Primer sensitivity}

The limit of detection of the X.c. pv. viticola specific fragment was determined by using a 10 -fold serial dilutions of purified genomic DNA of strains NCPPB 2475 and UnB 1183, and a $10^{9} \mathrm{CFU} / \mathrm{ml}$ suspension culture from strain NCPPB 2475. Aliquots of $2 \mu 1$ and $0.05 \mathrm{ml}$ were used for PCR amplification and colony counts on 523 medium, respectively.

\section{Detecting X.c. pv. viticola in symptomatic plant tissue}

Grapevine plants (cv. Perlette) were inoculated by pricking the petiole surface with a sterile needle charged with a 2-day-old culture of strain UnB1186. Three petioles were inoculated per plant and they were covered with plastic bags for $48 \mathrm{~h}$ after inoculation to maintain high humidity. Plants were kept under a shaded greenhouse and observed daily for symptom development. After 41 days, fragments of petioles were collected and used for PCR detection with primer pair RST2/ Xcv3R. The presence of X.c. pv. viticola in inoculated petioles, was investigated using three different methods as follow: (1) direct detection by macerating plant tissue in $500 \mu \mathrm{l}$ water and using $1 \mu \mathrm{l}$ for PCR amplification; (2) using a modified BIO-PCR protocol (27), in which aliquots of macerated tissue extracts were plated on 523 medium and after $72 \mathrm{~h}$ the surface of the medium was washed with $1 \mathrm{ml}$ of sterile water, and $1 \mu \mathrm{l}$ of the plate wash was used for PCR, and (3) macerated tissue extracts were plated on 523 medium, after $72 \mathrm{~h}$ one single suspect colony was collected in $200 \mu \mathrm{l}$ of water and $1 \mu 1$ was used for PCR.

\section{RESULTS AND DISCUSSION}

The amplification of a $h r p B$-gene region from X.c. pv. viticola and other xanthomonads was reproducible and produced an amplicon of approximately 840 bp for all strains tested. PCR products were partially sequenced and three primers were designed (Figure 1). These primers were tested in five combinations with previously designed primers RST2 and RST3 (12): (1) RST2/Xcv3R; (2) RST2/Xcv2R; (3) Xcv1F/Xcv3R; (4) Xcv1F/Xcv2R, and (5) Xcv1F/RST3. Combinations (2) and (4) did not yield any amplified product, while combination (5) produced a fragment of expected size ( $700 \mathrm{bp})$, but also several nonspecific secondary bands. Primer combinations (1) and (3) gave the expected amplicons of 340 and $240 \mathrm{bp}$, respectively, with DNA from X.c. pv. viticola (Figure 1). Therefore, these two latter sets of primers were selected and tested for specificity.

Amplification was positive for all 44 X.c. pv. viticola strains tested with these two sets of primers, RST2/Xcv3R and Xcv1F/Xcv3R. However, amplification was also positive with DNA from four X.c. pv. mangiferaeindicae strains and from five strains of $X . a . \mathrm{pv}$. passiflorae, as detected on ethidium-bromide stained agarose gels (Figure 2). Specificity of both primer pairs were also tested with genomic DNA from strains of other six genera of phytopathogenic bacteria, grape leaves and a total of 20 epiphytic and/or endophytic bacteria isolated from grape leaves, and no detectable product was observed (Figure 2).

A differentiation of the strains of X.c. pv. viticola from the strains of X.c pv. mangiferaeindicae and X.a. pv. passiflorae was performed with an additional restriction digestion step of the PCR products. Polymorphism was detected among the strains belonging to the three pathovars. HaeIII digestion of RST2/Xcv3R-amplified products generated distinct banding patterns for each pathovar. Strains of X.c. pv. viticola yielded 5 bands with approximately $100,70,60,55$ and $25 \mathrm{bp}$, while strains of X.c. pv. mangiferaeindicae showed two distinct restriction profiles and $X . a$. pv. passiflorae strains showed only one profile, with 3 fragments of approximately 250, 65 and $45 \mathrm{bp}$ (Figure 3).

Although they can be considered semi-specific since amplification was also positive with X.c pv. mangiferaeindicae and X.a. pv. passiflorae, it is unlikely that strains of these pathogens would be found infecting grapevines under field conditions. Moreover, the size of the amplified RST2/Xcv3R product is suitable for restriction digestion and visualization in agarose gels, if additional confirmation is required. All X.c. pv. viticola tested strains produced the same restriction profile, distinct from the other two pathovars. Taxonomic and phylogenetic relationships among X.c pv. viticola and these two pathovars have not been investigated. Interestingly, pathovars viticola and mangiferaeindicae share many similarities: they were both first described in India, some strains are not yellow pigmented and they have similar disease cycles and epidemiology. Their relationship should be more carefully studied.

The detection limit for primer pair Xcv1F/Xcv3R was $10 \mathrm{pg}$ of purified DNA. Primer pair RST2/Xcv3R was more sensitive, and allowed the detection of $1 \mathrm{pg}$ of bacterial DNA per reaction (Figure 4A). The same level of sensitivity was reported for a PCR assay developed for Erwinia amylovora (5), and for Xanthomonas albilineans (22), but for X. oryzae pv. oryzae, a visible band was detected with as low as $55 \mathrm{fg}$ of purified DNA (25). When serial dilutions of bacterial cell suspensions were used directly in the reaction (from $10^{9}$ to 10 $\mathrm{CFU} / \mathrm{ml}$ ) a detectable product was visible up to $10^{4} \mathrm{CFU} / \mathrm{ml}$ (Figure 4B), which corresponded roughly to 20 cells per reaction tube. A 1:50 dilution of the PCR products obtained with primers RST2/Xcv3R was used in a second round of amplification with the internal primer $\mathrm{Xcv} 1 \mathrm{~F}$ and primer Xcv3R. This nested-PCR approach increased sensitivity 100 -fold, and as low as $10^{2} \mathrm{UFC} / \mathrm{ml}$ could be detected (Figure 4C). This corresponded roughly to less than one cell in the reaction. Levels of sensitivity as high as $1 \mathrm{CFU}$ or less per reaction have been reported (16). High primer sensitivity is important for direct detection in plant tissue and for detecting bacteria in latent infections when pathogen population is low (below $10^{5} \mathrm{CFU} / \mathrm{ml}$ ) (5).

When primers RST2 and Xcv3R were used to detect X.c. pv. viticola in artificially inoculated petioles, amplification was positive only when an additional growth step was included. The bacterium could not be detected when suspensions were prepared from macerated tissue and used directly in the reaction mixture, probably due to the presence of PCR inhibitors. Lower sensitivity and inhibitors problems can be circumvented with the addition of an enrichment step, such as BIO-PCR, which has the advantage that only viable cells multiply and give a positive amplification signal (27). Moreover, sensitivity of BIO-PCR assays is extremely high, detecting as few as 1-2 CFU/ml (28).

In this study, an enrichment step was employed but bacterial 
NCPPB 2475

764

1111

NCPPB 2475

764

1111

NCPPB 2475

764

1111

NCPPB 2475

764

1111

NCPPB 2475

764

1111

NCPPB 2475

764

1111

NCPPB 2475

764

1111

NCPPB 2475

764

1111

NCPPB 2475

764

1111

NCPPB 2475

764

1111

NCPPB 2475

764

1111

NCPPB 2475

764

1111

NCPPB 2475

764

1111

NCPPB 2475

764

1111
CTATGGACGCTGC-GCGGCGCGCTTCGACGCGGTCGCCACCGAGGCGGGCTGGACCCTGC 59 -----TACGCTGCAGCGGCGTGCGTTCACGCAG-CGACTCGGTGGCGGACTAGGGCC $\overline{C G T} 54$ ------------- GGCGCGCTTCGACGCGG-CGCTAC-GAGGCGGGCTGGACCCTGC 42

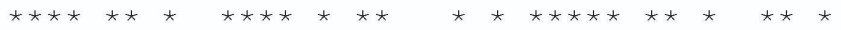

AGG--TGAGCTGTGCG---GCGAT--CCGATCT--GGCCGTGGGCGCCTGCGTGTGCGA- 109 TCGCCTACGTTCTGTGCTCGCGACTGCCGATCTCGAGGCGCTAGAACCTGCGTGTGCCA- 113 AAA--TAGA---TGTGTCGGCGAT--CCGACCT--GGCCGTGGGCGCCTGCGTGTGCGAC 93

GTGGGA--TACGGGAGTGTTCGAGACCG--ATCTGCGCGACCAGC-TGCGCAGTCTGCGG 164 GTGGGCACTACGGGAGTGTTCGAGACCGCAGTCTGCGCGACCAGCCTGCGCAGTCTGCGG 173 ATGGGA--CACGGGCGT-TTCGAGACCG--ATCTGCGCGATCAGC-TGCGCAGTCTGCGG 147

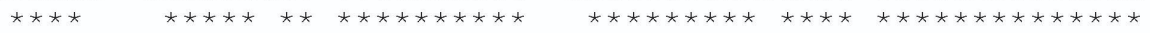

CGCGTCATTCGCCGCGTGTTGGCCGCACCCCAGGAGCCCGTGGATGCTGGCTGAGATGCC 224 CGCGTCATACGCCGCGTGTTGGCCGCACCCCAGGAGCCCGTGGATGCTGGCTGAGATGCC 233 CGCGTCATTCGTCGTGTATTGGCTGCACCGGAGGAGCTCGCGGATGCTGGCTGAGACGCC 207 C

XCV3R

CCTGCTGGAGACAGCGCTCGAGCGCGAGCTGGCCACGCTCGCGTTCGGCCGTCGCTATGG 284 CCTGCTGGAGACAGCGCTCGAGCGCGAGCTGGCCACGCTCGCGTTCGGCCGTCGCTGTGG 293 CCTGCTGGAGACAACGCTCGAGCGCGAACTGGCCACGCTCGCGTTCGGTCGTCGCTACGG 267

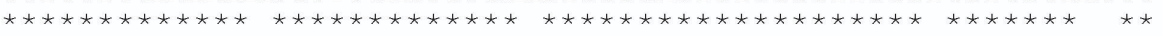

CAAGGTGGTCGAACTCGTCGGCACCATGCTCAAGGTGGCCGGCGTGCAGGTCAGCCTGGG 344 CAAGGTGGTCGAACTCGTCGGCATCATGCTCAAGGTGGCCGGCGTGCAGGTCAGCCTGGG 353 CAAGGTGGTCGAAGTCGTCGGCACCATGCTCAAGGTGGCCGGCGTGCAGGTCATCCTGGG 327

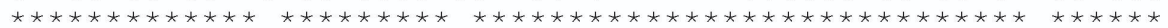

CGAGGTCTGCGAGTTACGCCAACGCGATGGCACCTTGTTGCAGCGTGCCGAATTGGTGGG 404 CGAGGTCTGCGAGTTGCGCCAACGCGATGGCACCTTGTTGCAGCGTGCCGAATTGGTGGG 413 CGAGGTGTGCGAGTTGCGCCAGCGCGATGGCAGCGTGTTGCAGCGGGCGGAGGTGGTGGG 387

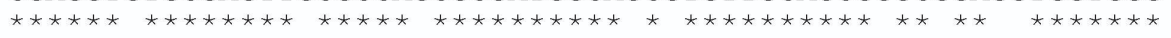

CTTCAGCCGCGATCTCGCATTGTTGGCGCCGTTCGGGGAGTTGGTCGGGCTGTCGCGCGA 464 CTTCAGCCGCGATCTCGCATTGCTGGCGCCGTTCGGGGAGCTGGTCGGGCTGTCGCGCGA 473 CTTCAGTCGCGATCTGGCGTTGCTGGCGCCGTTCGGCGAGCTGATCGGGCTGTCGCGCGA 447

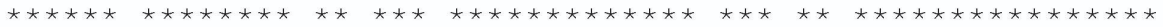

GACGCGCGTGATCGGATTGGGGCGCCCGTTGGCGGTGCCTGTT-GGACCGGCCTTGTTGG 523 GACGCGTGTGATCGGATTGGGGCGCCCGTTGGCGGTGCCTGTT-GGACCGGCCTTGCTGG 532 GACGCGCGTGATCGGATTGGGCCGCCCGTTGGCGGTGCCCGTTCGGACCGGCCTTGCTGG 507

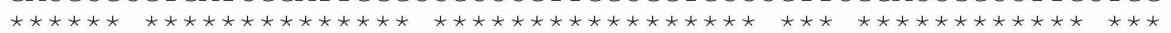

GGCGCGTGCTCGACGGCCTGGGCGAGCCGTCGGACGGGCAAGGAGCAATCGCCTGCGACA 583 GGCGCGTGCTCGACGGCCTGGGCGAGCCGTCGGACGGGCAAGGAGCAATCGCCTGCGACA 592 GGCGCGTTCTCGATGGCCTGGGCGTGCCGTCAGACGGGCAGGGAGCCATCGCCTGCGAAA 567

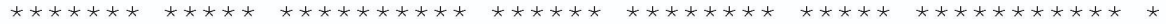

CCTGGGTTCCGATCCAGGCGCAGGCCCCGGACCCGATGCGTCGGCGGCTGATTGAACAAC 643 CCTGGATACCGATCCAGGCGCAGGCACCGGACCCCATACGTCGGCGGCTGATTGAACAAC 652 CCTGGGTACCGATCCAGGCGCAGGCACCGGAGCCAATGCGTCGGCGGCTGATTGAACACC 627

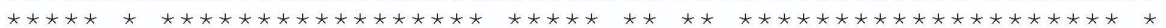

CCATGCCGACCGGGGTGCGGATCGTGGATTGCCTGATAACGCTTGGCGAGGGCCCACGCA 703 CCATGCCGACCGGCGTGCGGATCGTGGATTGCCTGATTACGCTTGGCGAAG-- - - - - - 703 CCATGCCGACCGGGGTGCGGATCGTGAATNGCCTGATAACGCTGGGCGAGGGCA-GCGCA 686

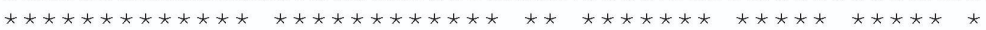

$\mathrm{XCV} 2 \mathrm{R}$

TGGGCATCTTCGCCGCAGCAGGCGTCGGCAGAGCACCTTGATGGAATTCGCCCGAGCANG 763

TTGGCATTT--- CGCCGACCGGGTTCGCAGAGCACTTATGGATTCCCCACCAAGAAAGA 742

GGGAATAA---------------------- 771

AAAAAAACAGGAAAGAACAATAACAACAAATA 774

Figure 1. Partial sequence alignment of the hrpB gene amplified with primers RST2 and RST3 from Xanthomonas campestris pv. viticola (NCPPB 2475), X. campestris pv. mangiferaeindicae (UnB 764) and X. axonopodis pv. manihotis (UnB 1111). Nucleotide identity is indicated by *; (-) alignment gaps and deletions; underlined and bold sequences indicate the three primers designed and synthesized in this study. 


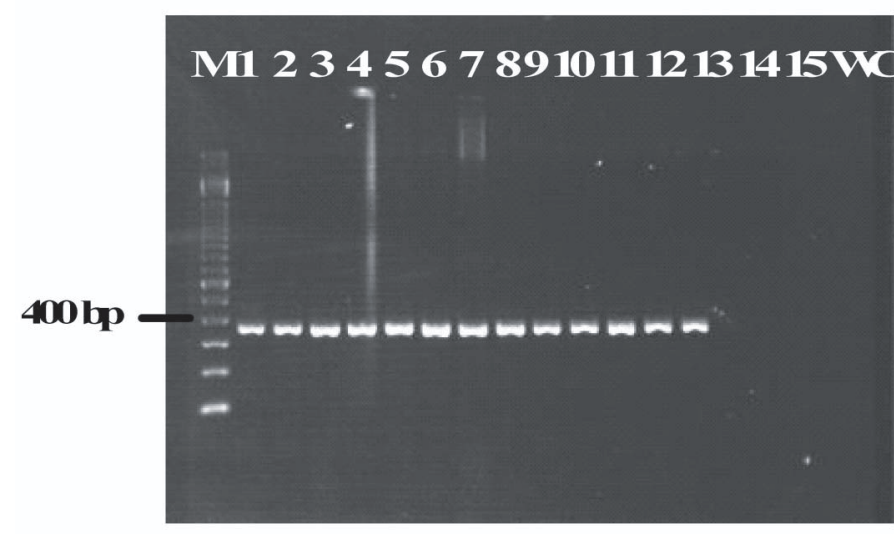

Figure 2. PCR amplification with primer pair RST2/Xcv3R, visualized on a $1 \%$ agarose gel. $\mathrm{M}$ - 100 bp-ladder (GIBCO/BRL); lanes (1)- NCPPB 2475; (2) - UnB - 1186; (3)- UnB 1187; (4)- IBSBF 1369; (5)- UnB 682; (6)- UnB 675; (7)- UnB 674; (8)- UnB 684; (9) - UnB 676; (10)- UnB 764; (11)- UnB 769; (12)- IBSBF 1230; (13)- IBSBF 1508; (14)- DNA from grape leaves; (15)- Ralstonia solanacearum and WC- negative water control. Lanes $1-4$ : Xanthomonas campestris pv. viticola; Lanes 5- 9: X. axonopodis pv. passiflorae, lanes 10-13: X.c. pv. mangiferaeindicae.

$\begin{array}{lllllllllllllllll}\text { M1 } & 1 & 2 & 3 & 4 & 5 & 6 & 7 & 8 & 9 & 10 & 11 & 12 & 13 & 14 & 15 & \text { M2 }\end{array}$

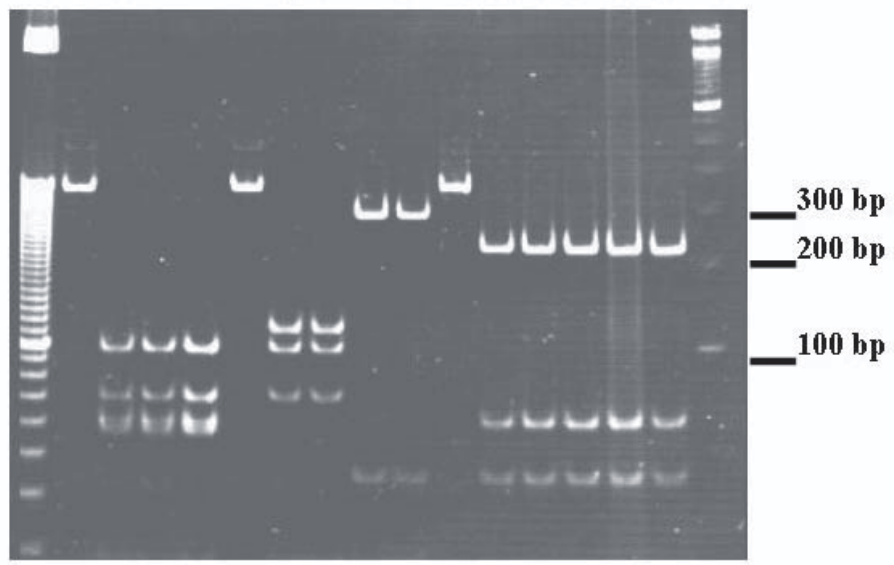

Figure 3. HaeIII- restriction digestion of PCR products amplified with primers RST2/Xcv3R separated on $21 \%$ polyacrylamide gel. M1: $10 \mathrm{bp}$ ladder; M2: 100 bp ladder; lanes (1)-NCPPB 2475 - undigested product; (2)-NCPPB 2475; (3)- UnB 1186; (4)- UnB 1187; (5)- UnB 764 undigested product; (6)- UnB 764; (7)- UnB 769; (8)- IBSBF 1230; (9)IBSBF1508; (10)- UnB 682 - undigested; (11)- UnB 682; (12)- UnB 675; (13)- UnB 674; (14)- UnB 684; (15) - UnB 676. Lanes 1 - 4: Xanthomonas campestris pv. viticola; lanes 5- 9: X.c. pv. mangiferaeindicae; lanes 10-15: X. axonopodis pv. passiflorae.
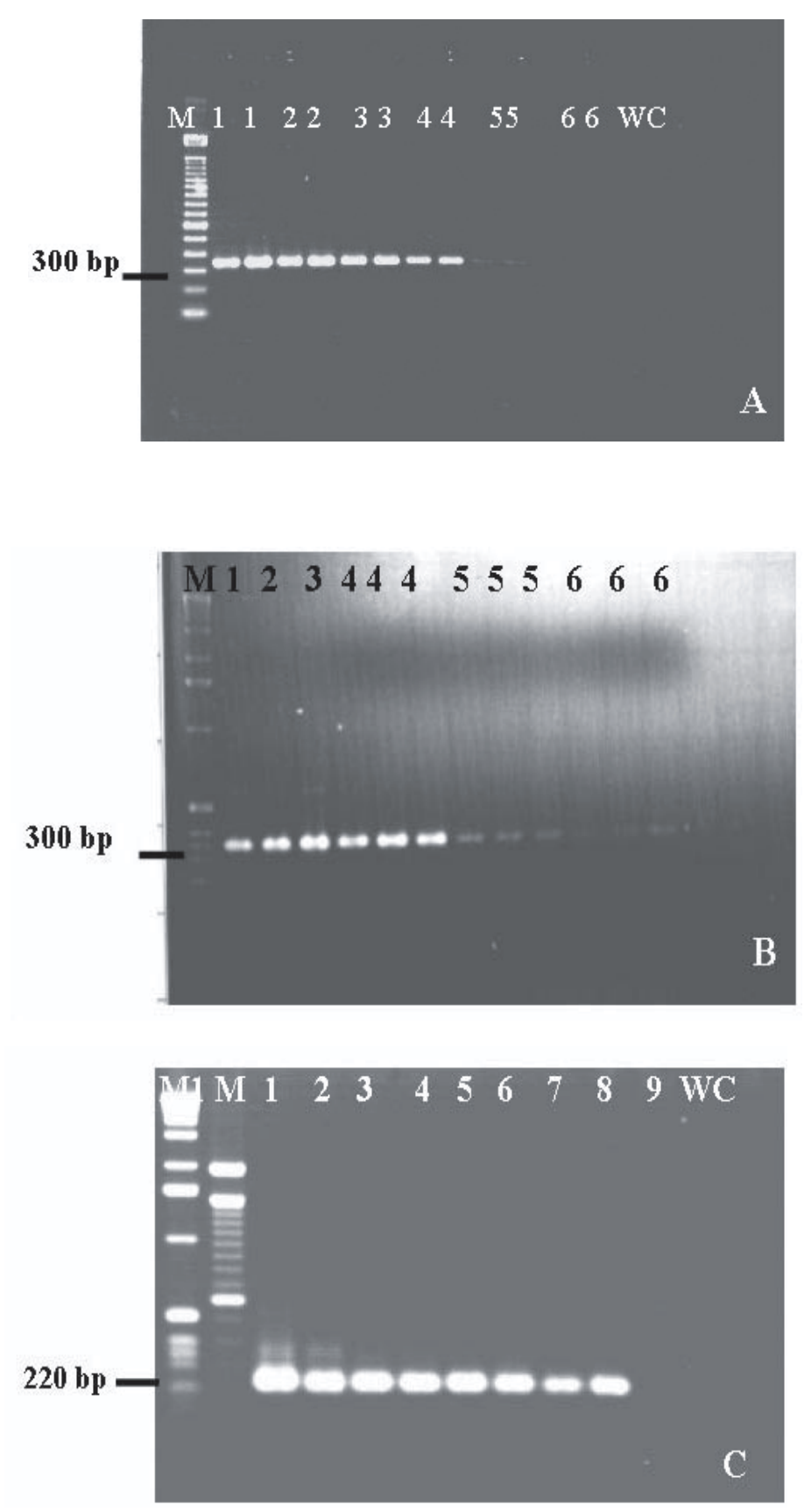

Figure 4- Detection limit of Xanthomonas campestris pv. viticola DNA amplified with primers RST2/Xcv3R. (A)- Dilution series of DNA from strain NCPPB 2475. M-100 bp ladder; Lane 1- $10 \mathrm{ng}$; 2- $1 \mathrm{ng}$; 3- 0,01 ng; 4- 0,001 ng; 5- 0,0001 ng; 6- 0,00005 ng; WC - water control. (B)Dilution series of a cell suspension of strain NCPPB 2475. Lane 1- $10^{9}$ $\mathrm{CFU} / \mathrm{ml} ; 2-10^{8} \mathrm{CFU} / \mathrm{ml} ; 3-10^{7} \mathrm{CFU} / \mathrm{ml} ; 4-10^{6} \mathrm{CFU} / \mathrm{ml} ; 5-10^{5} \mathrm{CFU} / \mathrm{ml}$; 6- $10^{4} \mathrm{CFU} / \mathrm{ml}$.(C)- Nested-PCR with primers Xcv1F/Xcv3R. PCR products obtained with primers RST2/ Xcv3R (Fig. 4B) were diluted (1:50) and used as templates. M1- 1 Kb ladder; M- 100 bp ladder; lane 1$10^{9} \mathrm{CFU} / \mathrm{ml} ; 2-10^{8} \mathrm{CFU} / \mathrm{ml} ; 3-10^{7} \mathrm{CFU} / \mathrm{ml} ; 4-10^{6} \mathrm{CFU} / \mathrm{ml} ; 5-10^{5}$ $\mathrm{CFU} / \mathrm{ml}, 6-10^{4} \mathrm{CFU} / \mathrm{ml}, 7-10^{3} \mathrm{CFU} / \mathrm{ml}, 8-10^{2} \mathrm{CFU} / \mathrm{ml}, 9-10 \mathrm{CFU} / \mathrm{ml}$; WC- water control. 


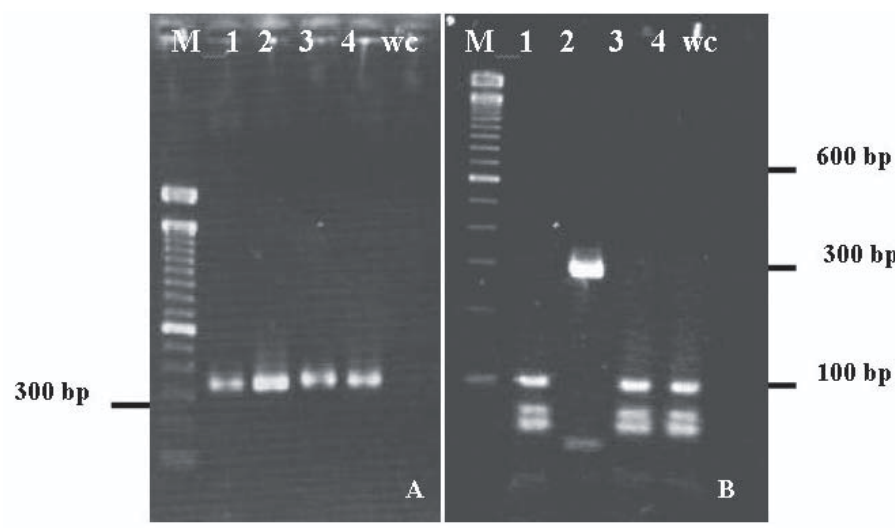

Figure 5. PCR-detection and identification of Xanthomonas campestris pv. viticola $(X c v)$ in inoculated and symptomatic grapevine petioles. (A) PCR with primers RST2/ Xcv3R: M- 100 bp DNA ladder; lane 1Xcv UnB 1186 (purified DNA); lane 2- X.c. pv. mangiferaeindicae IBSBF 1230 (purified DNA); lane 3- agar plate-washings from macerated tissue after $72 \mathrm{~h}$ incubation; lane 4 - one single colony of $X c v$ grown after $72 \mathrm{~h}$; and wc- water control. (B)- HaeIII- restriction digestion of PCR products amplified with primers RST2/Xcv3R separated on a $2,5 \%$ agarose gel. Same samples as in $5 \mathrm{~A}$.

colonies were only recovered from symptomatic petioles. No bacterial colonies were recovered from uninoculated petioles or from inoculated asymptomatic petioles, thus PCR could not be performed with samples from asymptomatic tissue. PCR was tested with aliquots of the plate wash obtained from symptomatic tissue and using a cell suspension from a single suspect colony. In both cases amplifications were positive (Figure 5A). Bacterium identity was confirmed by HaeIII digestion of PCR products, which produced the typical X.c. pv. viticola restriction profile (Figure 5B) and by observation of some cultural and biochemical characteristics of the colonies. Lack of yellow pigmentation, a positive reaction in the potassium hydroxide $(3 \% \mathrm{KOH})$ solubility test, and lack of growth on asparagin medium were all in accordance with the PCR-based identification assay.

Total time required for X.c. pv. viticola PCR-based detection and identification was 3 to 4 days, which was an advantage of the method when compared to the conventional techniques (at least 10 days for isolation, culturing, and identification by traditional bacteriological and pathogenicity tests). Although PCR has proven to be a very useful method for disease diagnosis and detection of various pathogens, potential problems such as contamination, false negatives and higher cost compared to serological detection, must be considered before adapting protocols for routine or large-scale testing (19).

Plant pathogenic bacteria, represented by diverse populations in the environment, often require complementary and multiple tests for identification (2). A PCR- detection and identification method could be very useful as an additional tool for monitoring X.c. pv. viticolacontaminated plant material. In this study, primers targeted to a pathogenicity gene were shown to specifically amplify DNA from X.c. pv. viticola and did not amplify host plant DNA or bacterial DNA from grapevine microflora. Our results showed that PCR could be used to detect and identify the pathogen in symptomatic plant tissue. Evaluation of PCR to detect X.c. pv. viticola in different plant parts as well as in asymptomatic grapevines will be the subject of future studies.

\section{ACKNOWLEDGEMENTS}

This research was supported by CNPq (Proc. 475111/2003-6), which also provided scholarships to E. Marques and L.C. Trindade.

\section{REFERENCES}

1. Altschul, S.F.; Gish, W.; Miller, W.; Meyers, E.W.; Lipman, D.J. Basic local alignment search tool. Journal of Molecular Biology, London, v. 215, p. 403-410, 1990.

2. Alvarez, A.M. Integrated approaches for detection of plant pathogenic bacteria and diagnosis of bacterial diseases. Annual Review of Phytopathology, Palo Alto, v.42, p. 339-366, 2004.

3. Araújo, J.S P.; Reis Júnior, F.B.; Cruz, G.B.; Oliveira, B.C.; Robbs, C.F.; Ribeiro, R.L.D.; Polidoro, J.C. Produção e caracterização de anticorpos policlonais contra Xanthomonas campestris pv. viticola. Pesquisa Agropecuária Brasileira, Brasília, v.40, n.3, p.305-309, 2005.

4. Ausubel, F.M.; Brent, R.; Kingston, R.E.; Moore, D.D.; Seidman, J.G.; Smith, J.A.; Struhl, K. (Ed.) Short protocols in molecular biology. $3^{\text {rd }}$ ed. New York: Wiley \& Sons, 1995.

5. Bereswill, S.; Pahl, A.; Bellemann, P.; Zeller, W.; Geider, K. Sensitive and species-specific detection of Erwinia amylovora by polymerase chain reaction analysis. Applied and Environmental Microbiology, Washington, v.58, n.11, p.3522-3526, 1992.

6. Bradbury, J.F. Guide to plant pathogenic bacteria. Kew: CAB International, 1986.332p.

7. Doyle, J.J.; Doyle, J.L. Isolation of plant DNA from fresh tissue. Focus, Gaithersburg, v. 12, p.13-15, 1987.

8. Freire, F.C.O; Oliveira, A.D.S. Ocorrência do cancro bacteriano da videira no Estado do Ceará. Comunicado Técnico Embrapa, Fortaleza, n.62, 2001

9. Gagnevin, L.; Leach, J.E.; Pruvost, O. Genomic variability of the Xanthomonas pathovar mangiferaeindicae of mango bacterial black spot. Applied and Environmental Microbiology, Washington, v. 63, n.1, p. 246-253, 1997.

10. Kado, C.I.; Heskett, M.G. Selective media for isolation of Agrobacterium, Corynebacterium, Erwinia, Pseudomonas and Xanthomonas. Phytopathology, St. Paul, v. 60, p. 969-976, 1970.

11. Kerkoud, M.; Manceau, C.; Paulin, J.P. Rapid diagnosis of Pseudomonas syringae pv. papulans, the causal agent of blister spot of apple, by polymerase chain reaction using specifically designed $h r p L$ gene primers. Phytopathology, St. Paul, v. 92, n.10, p.1077-1083, 2002.

12. Leite Jr., R.P.; Minsavage, G.V.; Bonas, U.; Stall, R. E. Detection and identification of phytopathogenic Xanthomonas strains by amplification of DNA sequences related to the hrp genes of Xanthomonas campestris pv. vesicatoria. Applied and Environmental Microbiology, Washington, v.60, n.4, p.1068-1077, 1994.

13. Leite Jr., R.P.; Jones, J.B.; Somodi, G.C.; Minsavage, G.V.; Stall, R.E. Detection of Xanthomonas campestris pv. vesicatoria associated with pepper and tomato seed by DNA amplification. Plant Disease, St. Paul, v. 79, n.9, p.917-922, 1995.

14. Lima, M.F.; Ferreira, M.A.S.V.; Moreira, W.A.; Dianese, J.C. Bacterial canker of grapevine in Brazil. Fitopatologia Brasileira, Brasília, v.24, n.3, p.440-443, 1999.

15. Lindgren, P.B.; Peet, R.C.; Panopoulos, N. J. Gene cluster of Pseudomonas syringae pv. phaseolicola controls pathogenicity of bean plants and hypersensitivity on nonhost plants. Journal of Bacteriology, Washington, v.168, n.2, p.512-522, 1986.

16. Louws, F.J.; Rademaker, J.L.W.; De Bruijn, F.J. The three Ds of PCRbased genomic analysis of phytobacteria: diversity, detection, and disease diagnosis. Annual Review of Phytopathology, Palo Alto, v.37, p.81-125, 1999

17. Malavolta Junior, V.A.; Almeida, I.M.G.; Sugimori, M.H.; Ribeiro, I.J.A; Rodrigues Neto, J.; Nogueira, E.M.C. Xanthomonas campestris pv. viticola em videira no Estado do Piauí. Summa Phytopathologica, Jaboticabal, v.25, n.1, p.27 1999a.(Resumo).

18. Malavolta Junior, V.A.; Almeida, I.M.G.; Sugimori, M.H.; Ribeiro, I.J.A.; Rodrigues Neto, J.; Pires, E.J.P.; Nogueira, E.M.C. Ocorrência de Xanthomonas campestris pv. viticola em videira no Brasil. Summa Phytopathologica, Jaboticabal, v.25, n.3, p.262-264, 1999b.

19. Martin, R.R.; James, D.; Lévesque, C.A. Impact of molecular diagnostic technologies on plant disease management. Annual Review of Phytopathology, Palo Alto, v.38, p. 207-239, 2000. 
20. Nascimento, A.R.P.; Mariano, R.L.R. Cancro bacteriano da videira: etiologia, epidemiologia e medidas de controle. Ciência Rural, Santa Maria, v.34, n.1, p.301-307, 2004.

21. Nayudu, M.V. Pseudomonas viticola sp. nov., incitant of a new bacterial disease of grape vine. Phytopathologische Zeitschrift, Berlin, v.73, p.183-186, 1972.

22. Pan, Y.-B.; Grisham, M.P.; Burner, D.M.; Legendre, B.L.; Wei, Q. Development of polymerase chain reaction primers highly specific for Xanthomonas albilineans, the causal bacterium of sugarcane leaf scald disease. Plant Disease, St. Paul, v.83,n.3, p.218-222, 1999.

23. Roberts, P.D.; Jones, J.B.; Chandler, C. K.; Stall, R.E.; Berger, R.D. Survival of Xanthomonas fragariae on strawberry in summer nurseries in Florida detected by specific primers and nested polymerase chain reaction. Plant Disease, St. Paul, v. 80, n.11, p.1283-1288, 1996.

24. Rozen, S.; Skaletsky, H.J. Primer3 on the WWW for general users and for biologist programmers. In: Krawetz S, Misener S (Ed). Bioinformatics methods and protocols: methods in molecular biology. Totowa, NJ: Humana Press, 2000. p. 365-386. Disponível em:<http://fokker.wi.mit.edu/primer3/>. Acesso em:28 maio 2002.
25. Sakthivel, N.; Mortensen, C.N.; Mathur, S.B. Detection of Xanthomonas oryzae pv. oryzae in artificially inoculated and naturally infected rice seeds and plants by molecular techniques. Applied Microbiology and Biotechnology, Berlin, v.56, n.3/4, p.435$441,2001$.

26. Sanger, F.; Nicklen, S.; Coulson, A.R. DNA sequencing with chainterminating inhibitors. Proceedings of the National Academy of Sciences, USA, Washington, v.74, n.12, p.5463-5467, 1977.

27. Schaad, N.W.; Cheong, S.S.; Tamaki, S.; Hatziloukas, E.; Panapoulos, N.J. A combined biological and enzymatic amplification (BIO-PCR) technique to detect Pseudomonas syringae pv. phaseolicola in bean seed extracts. Phytopathology, St. Paul, v.85, n.2, p. 243-248, 1995.

28. Song, W.Y.; Kim, H.M.; Hwang, C.Y.; Schaad, N.W. Detection of Acidovorax avenae subsp. avenae in rice seeds using BIO-PCR. Journal of Phytopathology, Berlin, v.152, p. 667-676, 2004

29. Thompson, J.D.; Higgins, D.G.; Gibson, T.J. CLUSTAL W: Improving the sensitivity of progressive multiple sequence alignment through sequence weighting, position-specific gap penalties and weight matrix choices. Nucleic Acids Research, Oxford, v. 22, p.4673-4680, 1994 